\title{
ARTIKELEN
}

\section{Drie kernthema's uit de evaluatie van de Wkkgz}

\author{
prof. mr. J. Legemaate, mr. dr. R.P. Wijne, mr. L.J. Knap E prof. dr. R.D. Friele ${ }^{*}$
}

\section{Inleiding}

In 2020 is voor de eerste keer de Wet kwaliteit, klachten en geschillen zorg (Wkkgz) geëvalueerd. In dit artikel doen we verslag van de belangrijkste uitkomsten van deze evaluatie. We besteden aandacht aan de context van de Wkkgz en aan de hoofdconclusies van het onderzoek (par. 2). Vervolgens zoomen we in op drie onderwerpen die in het evaluatieonderzoek met name in het oog sprongen: de relatie tussen de Wkkgz en nieuwe ontwikkelingen in de zorg, de wettelijke regeling van de meldplichten en ervaringen met betrekking de geschilleninstanties (par. 3). In de evaluatie kwamen uiteraard ook veel andere thema's aan de orde. Daarvoor verwijzen we naar het onderzoeksrapport. ${ }^{1}$ We sluiten af met een korte slotbeschouwing (par. 4).

\section{Voorgeschiedenis en doelstellingen van de Wkkgz}

Met betrekking tot de Wkkgz is sprake van een bijzondere ontstaansgeschiedenis. ${ }^{2}$ Rond 2010 streefde de overheid naar een brede wettelijke regeling van de patiëntenrechten. Deze nieuwe wet zou, gezien vanuit de positie van de patiënt, het sluitstuk moeten zijn van de ontwikkeling in beleid en wetgeving die werd ingezet met de stelselherziening van 2006. In de regelgeving zouden dan de Zorgverzekeringswet / Wet langdurige zorg, de Wet marktordening gezondheidszorg en de nieuwe patiëntenwet in samenhang met elkaar functioneren. De regering diende bij de Tweede Kamer een wetsvoorstel Cliëntenrechten zorg (Wcz) in, maar besloot enkele jaren later dit voorstel in te trekken, naar aanleiding van brede kritiek in het parlement, de literatuur en het veld van de gezondheidszorg. In plaats daarvan werd besloten tot enkele minder ingrijpende wetsaanpassingen, waaronder het vervangen van de Kwaliteitswet zorginstellingen (Kwz) en de Wet klachtrecht cliënten zorgsector (Wkcz) door de Wkkgz.

Bij de omvorming van de oorspronkelijke Wcz naar een afgeslankte Wkkgz heeft de discussie over de doelstellingen van de wet een meer specifieke richting gekregen, waarin twee elementen centraal zijn komen te staan: het verbeteren van de kwaliteit van zorg en het versterken van de rechtspositie van de patiënt. Uit de opzet van de Wkkgz vloeit voort dat deze beide doelen steeds in samenhang met elkaar moeten worden gezien. Het is niet

* Johan Legemaate is als hoogleraar gezondheidsrecht verbonden aan de UvA (Law Center for Health and Life). Rolinka Wijne is als docent/onderzoek gezondheidsrecht verbonden aan de UvA (Law Center for Health and Life). Linda Knap is als onderzoeker werkzaam bij het Nivel. Roland Friele is adjunct-directeur van het Nivel en bijzonder hoogleraar bij TRANZO (Tilburg University).

1 R.D. Friele e.a., Evaluatie Wet kwaliteit, klachten en geschillen zorg. Den Haag: ZonMw, 2021.

2 H.J.J. Leenen e.a., Handboek gezondheidsrecht. Den Haag: Boom juridisch, 2020, p. 104-106. 
zo dat het ene deel van de Wkkgz over de ene doelstelling gaat en het andere deel over de andere. In alle gevallen is steeds de vraag aan de orde wat de beste verhouding is tussen beide genoemde doelen, zowel met betrekking tot specifieke onderdelen van de wet als met betrekking tot de wet als geheel. Een wetsonderdeel dat met name de rechtspositie van de patiënt betreft, kan het beleid inzake verbetering van de kwaliteit van zorg zowel stimuleren als tegenwerken. Omgekeerd is dat ook zo. Van belang is zo veel mogelijk 'alignment' tussen beide doelen van de wet te realiseren, maar omdat het om twee eigenstandige doelen gaat, is dat niet altijd mogelijk. De evaluatie laat in algemene zin zien dat de verhouding tussen beide doelen niet altijd eenvoudig is, en dat daarover ook verschillend kan worden gedacht. De patiënt moet krijgen wat hem toekomt, maar zo veel mogelijk door een samenstel van regels dat voor de zorgaanbieder hanteerbaar is en het andere doel van de wet niet onnodig belemmert.

De Wkkgz beoogt ook te borgen dat de kwaliteit van zorg van een voldoende niveau is en dat kan worden ingegrepen bij misstanden op dat gebied. Om die reden voorziet de wet ook in procedurele regelingen die het mogelijk maken dat de toezichthouder waar nodig handhavend kan optreden. Dit aspect van de wet kan spanning opleveren met de meer faciliterende en stimulerende rol van de Wkkgz, maar het valt goed te begrijpen, ook gelet op de grondwettelijke eindverantwoordelijkheid van de overheid voor de toegankelijkheid en kwaliteit van de zorg, dat in de Wkkgz beide invalshoeken te vinden zijn. Waar het om gaat, is dat beide invalshoeken met elkaar in balans zijn. Voorkomen moet worden dat de overheid in situaties van gebrekkige of ondermaatse kwaliteit van zorg haar verantwoordelijkheid niet kan nemen, maar ook dat een op de motivatie en bereidheid tot leren gebaseerd kwaliteitssysteem wordt gefrustreerd door te formele benaderingen en procedures. Het is duidelijk dat de ontwikkelingen rond de kwaliteit van zorg zich in een ander stadium bevinden dan ten tijde van het voorbereiden van de Wkkgz het geval was. Dat kan om aanpassing van nu in de wet opgenomen instrumenten vragen.

Een van de twee voorgangers van de Wkkgz, de Kwz, werd in de jaren negentig van de vorige eeuw nadrukkelijk gepositioneerd als een kaderwet, die zorgaanbieders veel ruimte gaf om zelf in te vullen hoe zij aan de algemeen geformuleerde wettelijke verplichtingen gingen voldoen. In het kader van de parlementaire behandeling van de Wkkgz stond dit uitgangspunt minder centraal, omdat aan deze wet, in vergelijking met de Kwz, onderdelen werden toegevoegd die in termen van regulering een strikter karakter hebben (zoals de uitbreiding van de wettelijke meldplichten en de regeling inzake geschillen). ${ }^{3}$ Ook de centrale norm van de Wkkgz, het recht op goede zorg (art. $2 \mathrm{Wkkgz}$ ) kwam veel strakker in het pak te zitten door een expliciete koppeling met de kwaliteitsstandaard als geregeld in de Zorgverzekeringswet. ${ }^{4}$ Tegelijkertijd bevat de Wkkgz nog steeds onderdelen die vrijwel een-op-een zijn overgenomen uit de Kwz. Ten aanzien van die onderdelen moet worden aangenomen dat de oorspronkelijke gedachte daarachter (interpretatieruimte gekoppeld aan de eigen verantwoordelijkheid van de zorgaanbieder) nog steeds relevant is. Deze gedachte is ook leidend geweest bij het 'interne deel' van de klachten- en geschillenregeling

3 J. Legemaate, 'De Wkkgz over kwaliteit van zorg', TvGR 2016, p. 53-61.

4 Per 1 juli 2021 zullen de betreffende bepalingen uit de Zorgverzekeringswet worden overgeheveld naar de Wkkgz (Wet van 9 september 2020, Stb. 2020, 346). 
van de Wkkgz (de procedure waar de zorgaanbieder zelf verantwoordelijk voor is). Via die interpretatieruimte bestaat ook hier enige ruimte om te differentiëren tussen sectoren.

In het onderzoek wordt geconstateerd dat de beide doelen van de wet (het verbeteren van de kwaliteit van zorg en het versterken van de rechten van de patiënt), alsmede de samenhang ertussen, door het veld worden erkend en herkend. De algemene indruk is dat de wet aan het bevorderen van die beide doelen ook daadwerkelijk bijdraagt. In sectoren die voor 2016 te maken hadden met de Kwz en de Wkcz geldt dat de Wkkgz wordt gezien als een regeling die in het verlengde ligt van die beide eerdere wetten, en die in zoverre ook continuiteit van beleid vertegenwoordigt. Dat de overheid op een wijze als geregeld in de Wkkgz invulling geeft aan haar verantwoordelijkheid voor de kwaliteit van zorg en de rechten van patiënten heeft, zo blijkt uit het onderzoek, een breed draagvlak. Dat is ook het geval in de nieuwe sectoren die sinds 2016 onder deze wet vallen. Dat die sectoren soms nog moeite hebben om aan alle wettelijke verplichtingen te voldoen, doet daar niet aan af. De conclusie kan zijn dat de algemene uitgangspunten en doelstellingen alsmede het systeem van de Wkkgz niet ter discussie staan, en dat de toepassing daarvan in de praktijk een overwegend gunstig beeld laat zien. Van onoverkomelijke systeemproblemen is niet gebleken. De Wkkgz wordt in brede kring als een werkbare en nuttige wet gezien, die een duidelijke en logische plaats heeft in het geheel van de Nederlandse regelgeving op het terrein van de kwaliteit van zorg en de rechten van patiënten. Er is breed draagvlak voor een benadering waarin zorgaanbieders enerzijds ruimte en eigen verantwoordelijkheid hebben, maar de overheid anderzijds mogelijkheden heeft om toezicht te houden en te handhaven in situaties waarin de kwaliteit van zorg of de rechten van de patiënt te zeer onder druk komen te staan. Dat laat onverlet dat niet alle onderdelen van de wet positief worden beoordeeld. Daar gaan we in de volgende paragraaf op in.

\section{Drie thema's nader bezien}

In het evaluatieonderzoek worden in totaal 32 aanbevelingen gedaan over uiteenlopende onderwerpen uit of rond de Wkkgz. In deze bijdrage richten we ons op de conclusies en aanbevelingen met betrekking tot drie thema's:

- de Wkkgz en nieuwe ontwikkelingen in de zorg;

- de regeling van de meldplichten;

- de geschilleninstanties.

Dit zijn de drie onderwerpen die in het onderzoek de meeste aandacht vroegen en tot de meest ingrijpende aanbevelingen hebben geleid. De met betrekking tot deze drie thema's gedane aanbevelingen zijn opgenomen in een bijlage bij dit artikel.

Thema 1: De Wkkgz en nieuwe ontwikkelingen in de zorg

Op tal van punten kwam tijdens het onderzoek de vraag aan de orde of de Wkkgz wel voldoende kan meebewegen met nieuwe ontwikkelingen in de zorg, bijvoorbeeld waar het gaat om de kenmerken van de sectoren die in 2016 voor het eerst onder deze kwaliteitswetgeving zijn gebracht. Waar in de Kwz het begrip 'instelling' centraal stond, heeft de Wkkgz het bredere begrip 'zorgaanbieder' als vertrekpunt. Onder dat begrip vallen niet 
alleen instellingen in de gebruikelijke zin van het woord, maar ook kleinere samenwerkingsverbanden, beroepsbeoefenaren in een solo-praktijk, de cosmetische sector en alternatieve zorgaanbieders. De wetgever achtte het van belang dat de in de Wkkgz neergelegde kwaliteitsbepalingen in de gezondheidszorg breed van toepassing zijn. Dat uitgangspunt, zo komt uit het onderzoek naar voren, wordt breed gedeeld. Dat betekent niet dat het toepassen van de wettelijke bepalingen in kleinere samenwerkingsverbanden altijd eenvoudig is. Vaak is dat niet zo, hetzij door het ontbreken van de (ondersteunende) menskracht die bijvoorbeeld in ziekenhuizen wel aanwezig is, hetzij door onduidelijkheid over hoe de wettelijke verplichtingen (zoals het hebben van een kwaliteitssysteem) in kleinere verbanden of solo-praktijken moeten worden toegepast. De systematiek van en vereisten uit de Wkkgz sluiten goed aan bij de praktijk van de grotere instellingen, maar leveren voor kleinschaliger praktijken vaak een grote uitdaging op. Om die reden wordt het belangrijk gevonden dat ruimte wordt geboden voor enige mate van differentiatie, in relatie tot de kenmerken en omstandigheden van bepaalde zorgsectoren. Dit betreft ook de intensiteit en de vormgeving van het toezicht.

Daar komt bij dat sommige onderdelen van de wet vooral relevant zijn in grotere organisatorische verbanden, en veel minder in kleinere zorgpraktijken of bij solistisch werkende beroepsbeoefenaren. In grotere organisatorische verbanden kan ook bij de uitvoering van wettelijke bepalingen veel makkelijker worden opgeschaald dan in situaties waarin de zorgaanbieder zoals bedoeld in de wet en de individuele zorgverlener min of meer samenvallen. Dat draagt er tevens aan bij dat de uitvoeringslasten van de wet bij kleinere zorgaanbieders verhoudingsgewijs hoog zijn. Bij kleinere zorgaanbieders en solo-praktijken zijn wel duidelijke stappen gezet, met name ook door initiatieven op het niveau van koepel- en brancheorganisaties. Dergelijke organisaties kunnen in termen van kennisverspreiding en ondersteuning een belangrijke rol spelen, vooral in domeinen waar de slag- en innovatiekracht van de (kleine) zorgaanbieder zelf beperkt is. Een specifiek punt van aandacht is wel dat in deze sectoren lang niet alle beroepsbeoefenaren zijn aangesloten bij een beroepsorganisatie, waardoor zij niet door deze organisaties geïnformeerd (kunnen) worden.

Een belangrijk thema binnen de gezondheidszorg is netwerkzorg. Dat is een aspect dat in de Wkkgz c.a. niet of nauwelijks aan de orde komt. De enige uitzonderingen zijn artikel 3 Wkkgz, dat spreekt van 'afstemmingsplichten', en artikel 7.3 lid 2 Uitvoeringsbesluit Wkkgz, dat voorziet in de mogelijkheid dat samenwerkende zorgaanbieders kunnen kiezen voor een gecombineerde behandeling van klachten. De toenemende netwerkzorg levert evenwel ook vragen op met betrekking tot andere onderdelen van de Wkkgz en de daarbij relevante verdeling van verantwoordelijkheden. In het onderzoek werd duidelijk dat veel respondenten zich bewust zijn van de toenemende netwerkzorg, maar dat de implicaties daarvan voor de interpretatie en toepassing van Wkkgz-bepalingen en verantwoordelijkheden nog niet echt doordacht zijn. Zowel in het veld als bij de Inspectie Gezondheidszorg en eugd (IGJ) spelen regelmatig vragen hierover, waarop niet altijd een duidelijk antwoord is te geven. ${ }^{5}$ Wie kan in zo'n situatie worden aangesproken op kwaliteit en veiligheid? Tot grote problemen heeft dat nog niet geleid, maar het onderwerp vraagt de 
komende jaren zeker doordenking en nadere uitwerking. ${ }^{6}$ Belangrijk is de probleemsituaties in kaart te brengen, om vervolgens een beredeneerde keuze te maken over hoe de toezichthouder zich in die situaties zal opstellen. Aangenomen moet worden dat de IGJ in het licht van de relatie tussen de doelen van de Wkkgz en het publieke belang enige ruimte heeft om in twijfelgevallen haar wettelijke mogelijkheden extensief te interpreteren.

In veel situaties is duidelijk welke persoon of organisatie zorgaanbieder in de zin van de Wkkgz is, maar in tal van gevallen ook niet. Dat is vooral een probleem voor de IGJ. Voor de toezichthouder is niet altijd helder op wie de wettelijke verantwoordelijkheden van de zorgaanbieder rusten. Dat kan aan de orde zijn bij zorgverlening in het kader van een franchiseconstructie, in situaties waarin de zorgcontracterende entiteit de uitvoering van de zorg geheel of gedeeltelijk uitbesteedt, bij organisaties waarbinnen sprake is van een combinatie van wel en niet onder de Wkkgz vallende activiteiten (zoals bijvoorbeeld bij een GGD, of een instelling die zowel aan therapie als aan coaching doet) en in situaties waarin er een hoofd- en een onderaannemer is. Belangrijk is dat, in de geest van de wet, een brede interpretatie van het begrip zorgaanbieder gehanteerd blijft worden, en dat constructies worden voorkomen waarin instellingen of organisaties hun verantwoordelijkheden op grond van de Wkkgz als het ware wegdelegeren, en onduidelijk wordt wie dan wel op die verantwoordelijkheden aanspreekbaar is. In bepaalde situaties ligt het voor de hand dat de wettelijke verantwoordelijkheden ten volle op meerdere partijen rusten, tenzij zij onderling een adequate verantwoordelijkheidsverdeling hebben afgesproken. In andere gevallen kan het nodig zijn te concluderen dat op een entiteit die ontkent Wkkgz-verantwoordelijkheden te hebben, deze verantwoordelijkheden wel degelijk rusten. Het is van belang ervoor zorg te dragen dat de Wkkgz de IGJ in staat stelt ook in dit soort situaties toezichthoudend op te treden. Te verwachten is dat een aanpassing van de Wkkgz die voortvloeit uit de Wet toetreding zorgaanbieders (Wtza) behulpzaam kan zijn. Deze aanpassing leidt tot een iets ruimere omschrijving van het begrip 'instelling' in artikel 1 lid 1 Wkkgz.

Aanbevelingen thema 1

Thema 1: De Wkkgz en nieuwe ontwikkelingen in de zorg

- Aanbeveling 1: Benut binnen het algemene kader van de Wkkgz de mogelijkheden voor sectorale differentiatie van kwaliteitssystemen.

- Aanbeveling 3: Stimuleer in sectoren waarin voornamelijk kleine zorgaanbieders werkzaam zijn de rol van branche- en koepelorganisaties bij het interpreteren en implementeren van de wettelijke verplichtingen.

- Aanbeveling 6: Voeg aan de Wkkgz een bepaling toe die inhoudt dat zorgaanbieders die met elkaar samenwerken in een netwerk geacht worden afspraken te maken over het in dat kader realiseren van uit de wet voortvloeiende verplichtingen.

- Aanbeveling 7: Ontwikkel in overleg tussen het ministerie, de toezichthouder en het veld een handreiking over de toepassing van de Wkkgz in situaties

6 Zie in dat kader ook de uitspraak van het CTG uit januari 2021 over de regiebehandelaar, CTG 29 januari 2021, ECLI:NL:TGZCTG:2021:36. 
waarin zorg wordt verleend in verschillende ondernemingsvormen en vormen van netwerkzorg.

- Aanbeveling 28: Ontwikkelen een toezichtkader dat zich specifiek richt op het houden van toezicht op 'lastige' organisatorische constructies.

Thema 2: De regeling van de meldplichten

Met het oog op de toekomstbestendigheid is het van groot belang dat de Wkkgz ruimte biedt voor kwaliteitsontwikkelingen in bredere zin, zoals bijvoorbeeld de Safety IIontwikkeling. ${ }^{7}$ Voorkomen moet worden dat de wet dergelijke ontwikkelingen belemmert, maar nog beter zou het zijn als de wet die ontwikkelingen stimuleert. Op dat punt worden bepaalde onderdelen van de wet als knellend ervaren. Daarbij gaat het met name om de regeldichtheid van de bepalingen in het Uitvoeringsbesluit Wkkgz inzake de verschillende meldplichten, en in het bijzonder de meldplicht calamiteiten. Tegelijkertijd is het maar de vraag of alle zorgaanbieders die onder de Wkkgz vallen al in voldoende mate 'lerende organisaties' zijn. Dat kan door wetgeving in zekere mate worden gestimuleerd, maar niet worden afgedwongen. Naast wetgeving zijn daarvoor juist ook andere initiatieven en ontwikkelingen vereist, zoals een open disclosure-beleid. ${ }^{8}$

De in de Wkkgz opgenomen meldplichten zijn belangrijk voor de kwaliteit van zorg, maar ook voor de bescherming van de patiënt. Maar het accent in de Wkkgz op meldplichten alsmede de daarbij behorende (afhandelings)procedures roepen wel vragen op. Die betreffen niet alleen de regeldichtheid en de daaruit voortvloeiende strikte handhaving, maar ook de meerwaarde van de meldplichten in de huidige vorm. Een te strikte interpretatie van de verschillende meldplichten kan er, zo wordt wel betoogd, toe leiden dat de verhouding tussen de verantwoordelijkheden van de overheid en die van het veld uit balans raakt. Daarvoor, zo is de breed gedeelde opvatting, moet wel worden gewaakt. De meldplichten leggen bovendien een groot beslag op inspectiecapaciteit en op de capaciteit bij zorgaanbieders, waarbij veel aandacht uitgaat naar het op een juiste manier melden en onderzoeken. De nadruk is komen te liggen op de procedure. Dit speelt vooral bij de calamiteitenmelding. Respondenten gaven aan dat ze door de wet heel goed zijn geworden in het melden en onderzoeken van calamiteiten, maar dat de meerwaarde daarvan voor het verbeteren van de patiëntveiligheid lang niet altijd duidelijk is. Sommigen concluderen dat melden een doel op zich is geworden. Het is goed mogelijk dat van een opener, flexibeler en motiverender systeem een grotere bijdrage aan de kwaliteit van zorg te verwachten is, die ook beter past bij de Safety-II gedachte, dan van de strikte wijze waarop de meldplichten thans in de Wkkgz c.a. worden geregeld. Dan kan ook gedacht worden aan een stelsel

7 'Uitgangspunt bij Safety II is dat patiëntveiligheid wordt vergroot door te focussen op aanpassingsvermogen en veerkracht (resilience) van professionals in de context waarin zij werken. Bij Safety II wordt veiligheid vanuit een positieve benadering onderzocht in haar AANwezigheid in plaats van onderzoek uitsluitend naar fouten en dus AFwezigheid van veiligheid. Dat wat dagelijks goed gaat wordt zichtbaar gemaakt en verbeterd; daarvan wordt geleerd en dit wordt verder ondersteund en verspreid' (www.zonmw.nl). Zie ook I. Leistikow \& R. Bal, 'Resilience and regulation, an odd couple? Consequences of Safety-II on governmental regulation of healthcare quality', BMJ Qual Saf 2020, p. 869-872. 
waarin meldingen niet stuk voor stuk, maar op een geïntegreerde wijze aan de IGJ worden voorgelegd, bijvoorbeeld halfjaarlijks.

Een in 2016 nieuw geïntroduceerde meldplicht is die betreffende de beëindiging van een overeenkomst met een beroepsbeoefenaar wegens ernstig tekortschieten in het functioneren (art. 11lid 1 onder c Wkkgz; hierna: meldplicht disfunctioneren). Een dergelijke melding wordt door de IGJ onderzocht. Oordeelt de IGJ op grond daarvan dat de melding terecht is gedaan, dan is de IGJ gerechtigd informatie over betrokkene te verstrekken aan een werkgever die in het kader van vergewisplicht bij de IGJ informatie over die persoon opvraagt. ${ }^{9}$ De ratio van deze bepaling is dat wordt voorkomen dat een ernstig disfunctionerende beroepsbeoefenaar na een ontslag bij de ene zorgaanbieder, weer makkelijk aan de slag kan bij een andere. Dit is een belangrijk thema, maar de uitkomsten van dit onderzoek roepen de vraag op in welke mate de meldplicht van artikel 11 lid 1 onder c Wkkgz daaraan werkelijk een bijdrage levert. De IGJ rapporteerde dat in 2017 en 2018416 ontslagmeldingen zijn ontvangen, waarvan er uiteindelijk 35 zijn geregistreerd. In de periode 2016-2019 ontving de IGJ 24.847 vergewisvragen. In geen van deze gevallen was er een match met een door de IGJ na eigen onderzoek geregistreerde casus van disfunctioneren. De meldplicht disfunctioneren dient twee mogelijke doelen:

1 de IGJ zicht geven op zorgverleners die wegens disfunctioneren wordt ontslagen;

2 voorkomen dat werkgevers zorgverleners die eerder hebben gedisfunctioneerd in dienst nemen of contracteren.

Het eerste doel is legitiem en past bij de doelstellingen van de wet. Dat de kwantitatieve opbrengst relatief gering is (35 registraties in 2016-2019), doet daar niet aan af.

Anders ligt het bij het tweede doel: het voorkomen dat een disfunctionerende beroepsbeoefenaar zomaar elders aan de slag kan gaan. Dit doel moet worden bereikt door de koppeling tussen de meldingen disfunctioneren en de vergewisplicht van zorgverleners. Dit aspect van de vergewisplicht stuit op problemen rond de uitvoerbaarheid van de regeling. Het reageren op de vergewisvragen vergt van de IGJ veel capaciteit en de baten zijn tot op heden nihil. De verhouding kosten-baten is zodanig uit balans dat de koppeling tussen de vergewisplicht en de meldplicht disfunctioneren heroverweging verdient.

Aanbevelingen thema 2

Thema 2: De regeling van de meldplichten

- Aanbeveling 4: Ontwikkel een toepassingskader met betrekking tot de Wkkgz waarin het belang van een lerende organisatie voorop wordt gesteld. Bied daarbij ruimte aan de IGJ om haar toezicht zo in te richten dat het bij de ontwikkelingsfase van de betreffende sector past (beroeps- en patiëntenorganisaties, in overleg met ministerie en toezichthouder).

- Aanbeveling 8: Heroverweeg de regeldichtheid betreffende de meldplichten in het Uitvoeringsbesluit Wkkgz. Geef de IGJ meer ruimte voor variatie bij het

9 J.M. de Vries \& B. van den Boom, 'Disfunctionerende hulpverleners. Vergewissen, dus niet te missen?', TvGR 2020, p. 606-618. 

afhandelen van meldingen, in relatie tot individuele zorgaanbieders dan wel tot sectoren (wetgever, ministerie, toezichthouder).
- Aanbeveling 9: Overweeg de keuze voor een model waarin zorgaanbieders niet langer individuele meldingen doen, maar halfjaarlijks of jaarlijks. Schrijf voor dat in dergelijke rapportages niet alleen aandacht wordt geschonken aan het interne onderzoek naar de meldingen als zodanig, maar ook aan de leereffecten en de gevolgen voor het algemene kwaliteitsbeleid (wetgever).
- Aanbeveling 16: Heroverweeg de koppeling tussen de vergewisplicht uit arti- kel 4 Wkkgz en de meldplicht disfunctioneren. Onderzoek of een (al dan niet verruimd) Waarschuwingsregister Zorg en Welzijn een alternatief kan bieden (wetgever).
- Aanbeveling 30: Verbeter de disseminatie van 'lessons learned' tussen zorgaan- bieders onderling en tussen de IGJ en het veld van de gezondheidszorg.

\section{Thema 3: De geschilleninstantie}

Waar het kwaliteitsdeel van de Wkkgz in belangrijke mate aansluit bij de opzet en inhoud van de eerdere Kwaliteitswet zorginstellingen, is dat bij de klachten- en geschillenregeling veel minder het geval. Ten aanzien van het laatste thema heeft de wetgever bewust voor een andere insteek gekozen dan die van de $\mathrm{Wkcz} .{ }^{10}$ Die wet schreef voor dat elke instelling diende te beschikken over een klachtencommissie met een onafhankelijke voorzitter. De Wkkgz kiest voor een opener systeem, dat bestaat uit een 'intern' deel en een 'extern' deel. Het 'interne' deel van de klachtenregeling van de Wkkgz is erop gericht de patiënt een laagdrempelige mogelijkheid voor het behandelen van klachten te bieden en de zorgaanbieder in dat kader zelf verantwoordelijkheid te laten nemen. Het 'externe' deel geeft de patiënt de mogelijkheid een oordeel te vragen van een onafhankelijke geschilleninstantie. Die instantie oordeelt over verzoeken om schadevergoeding, maar ook over klachten zonder een financiële component. Enerzijds dus een groot accent op de eigen verantwoordelijkheid van de zorgaanbieder, anderzijds een mogelijkheid voor de klager om een extern en onafhankelijk bindend oordeel te krijgen. De gedachte is dat de zorgaanbieder, wetende dat de patiënt naar de geschilleninstantie kan gaan, zich zal inspannen om goed te reageren op klachten en andere uitingen van onvrede. ${ }^{11}$

Een belangrijke innovatie in de Wkkgz is derhalve de onafhankelijke geschilleninstantie waarbij de zorgaanbieder zich dient aan te sluiten. Dergelijke geschilleninstanties bestonden in sommige deelsectoren van de zorg ook al voor 2016, ter afhandeling van kleinere claims ( $€ 5.000$ tot 10.000 ), maar door de Wkkgz is hun positie op drie punten gewijzigd:

- alle zorgaanbieders die onder de wet vallen zijn nu verplicht zich bij een erkende geschilleninstantie aan te sluiten;

- anders dan in de situatie voor 2016 oordelen deze geschilleninstanties niet alleen over verzoeken om schadevergoeding maar ook over klachten zonder een financiële component;

10 W.R. Kastelein, 'De Wkkgz is er: een nieuwe klachten- en claimregeling in de zorg!', TvGR 2016, p. 62-71.

11 B.S. Laarman \& A.J. Akkermans, 'De afwikkeling van medische schade onder de Wkkgz', TVP 2017, afl. 3, p. 57-79. 
- de grens van schadeclaims waarover de instanties kunnen oordelen is opgetrokken naar $€ 25.000$.

Over de geschilleninstantie valt op grond van het evaluatieonderzoek veel te zeggen. Deels gaat het om knelpunten die niet het wezen van de geschilleninstantie raken, maar meer te maken hebben met de organisatie en financiering, deels om meer fundamentele knelpunten.

Het evaluatieonderzoek signaleert ontwikkelingen die slecht aansluiten bij de met de Wkkgz beoogde ontwikkelingen. Allereerst dienen, vanuit het perspectief van patiënten, kritische kanttekeningen geplaatst te worden bij het functioneren van de geschilleninstantie. Over het proces bij de geschilleninstantie oordeelden onze respondenten minder vaak positief dan over het 'interne' deel van de Wkkgz-regeling: minder vaak ervaarden ze dat ze de ruimte kregen om hun verhaal te vertellen of voelden ze zich met respect behandeld. Slechts de helft van de respondenten bij de geschilleninstantie oordeelde dat ze zich serieus genomen voelden, terwijl dat voor vrijwel iedereen belangrijk was. Opvallend is dat slechts een minderheid van de indieners van een geschil de geschilleninstantie als onafhankelijk ervaren. En minder dan 20\% van hen denkt dat met het indienen van een geschil is voorkomen dat anderen hetzelfde zal gebeuren of dat hun klacht bijdraagt aan het verbeteren van de kwaliteit van zorg. Eerder onderzoek naar de voormalige klachtencommissie van de Wkcz laat zien dat mensen met een klacht bij de klachtencommissie veel vaker dan bij de huidige geschilleninstantie positief oordeelden over zowel het proces, als de ervaren onafhankelijkheid, de invloed van de klacht op de kwaliteit van zorg en de preventieve werking van de klacht voor de toekomst. ${ }^{12}$ We constateren dat de geschilleninstanties in de ogen van klagers op een aantal punten slechter scoren dan de vroegere klachtencommissies:

- de gepercipieerde onafhankelijkheid;

- het gevoel serieus genomen te worden;

- het voorkomen dat risico's voor de kwaliteit van zorg zich herhalen.

Het lijkt erop dat dit onder meer samenhangt met de 'afstand' tussen de zorgaanbieder en de geschilleninstanties en met de bemensing en formele aanpak van die instanties. Met name de juridische leden van de instanties hebben een hoofdbetrekking in formele verbanden, zoals de rechtspraak. Het lijkt erop dat de instanties de formele houding die in zekere mate vereist is bij de beoordeling van schadeclaims, ook toepassen in zaken zonder een financiële component. In die gevallen past een formele(re) aanpak juist niet. Kennelijk hadden de vroegere klachtencommissies daar een beter gevoel voor dan de huidige geschilleninstanties.

Daar komt bij dat de aanpak van de geschilleninstanties ook schaduwen vooruitwerpt naar het 'interne' deel van de Wkkgz-regeling. Tal van respondenten geven aan dat de formalisering op het niveau van de geschilleninstanties ook leidt tot een zekere formalisering van de 'interne' fase van de klachten- en geschillenregeling van de wet. Dit zet een belangrijke doelstelling van de wet, namelijk informele en laagdrempelige klachtenopvang op het niveau van de zorgaanbieder, onder druk. Dat klemt temeer nu de geschilleninstanties een

12 E.M. Sluijs, R.D. Friele \& J.E. Hanssen, WKCZ klachtbehandeling in ziekenhuizen: verwachtingen en ervaringen van clienten - Fase II: Ervaringen van cliënten met de WKCZ-klachtbehandeling in ziekenhuizen vergeleken met hun verwachtingen ten aanzien van de klachtbehandeling en de werkwijze van de klachtencommissies. Den Haag: ZonMw, 2004. 
andere aanname uit de parlementaire behandeling van de wet ook niet waarmaken: bijdragen aan een verbetering van de lastige positie van de patiënt in aansprakelijkheidskwesties. Dit roept verschillende vragen op:

- Hoe kan de verhouding tussen het 'interne' en het 'externe' deel van de klachten- en geschillenregeling worden geoptimaliseerd?

- Is het een goede keuze dat de geschilleninstanties zowel schadeclaims als klachten zonder financiële component behandelen?

- Is het systeem van de geschilleninstanties toegerust om bij te dragen aan de verbetering van de kwaliteit van zorg (feedbackloop klachten-kwaliteit)?

- Welke factoren staan in de weg aan een wezenlijke bijdrage van de geschilleninstanties aan het verbeteren van de lastige positie van de patiënt in aansprakelijkheidskwesties?

Ten slotte geldt dat de verwachting niet wordt waargemaakt dat de geschilleninstantie als alternatief zou kunnen dienen voor het 'klassieke' claimtraject. Jaarlijks wordt aan de geschilleninstanties een relatief beperkt aantal zaken voorgelegd. In gevallen waarin de instantie een verzoek van de patiënt om schadevergoeding inwilligt, ligt het gemiddeld toegekende bedrag net iets boven de $€ 2.000$. Dit wijst erop dat de instanties vooral bemoeienis hebben met kleinere claims. Bij ingewikkelder zaken ligt het primaat nog steeds bij de zorgaanbieder en zijn aansprakelijkheidsverzekeraar. Er is geen sprake van een verschuiving van aansprakelijkheidszaken richting de geschilleninstanties. De aansprakelijkheidsverzekeraars rapporteren wel een zekere stijging van het aantal schadeclaims en van de hoogte daarvan, maar die ontwikkeling was ook al zichtbaar voor de komst van de Wkkgz en lijkt door de inwerkingtreding van die wet niet te zijn beïnvloed. Het onderzoek laat zien dat deze twee trajecten nog steeds twee verschillende trajecten zijn.

Daarnaast blijken tussen geschilleninstanties aanzienlijke verschillen te bestaan, zowel waar het gaat om de in de instantie aanwezige expertise, de procedure die de instantie hanteert en de wijze waarop de schriftelijke uitspraak van de instantie is ingericht. Een zekere mate van variatie is onvermijdelijk en kan verband houden met kenmerken van bepaalde deelsectoren in de zorg, maar te grote verschillen op de genoemde punten moeten uit een oogpunt van rechtsbescherming en rechtseenheid als ongewenst worden beschouwd. In het kader van het onderzoek, dat een brede evaluatie van de Wkkgz behelsde, konden deze thema's slechts in beperkte mate worden onderzocht en geanalyseerd. De resultaten van dit onderzoek geven alle aanleiding dit onderdeel van de wet diepgaander te onderzoeken, bijvoorbeeld ook door studie te doen naar integrale klachttrajecten ('interne' en 'externe' fase Wkkgz). Het is verstandig daarmee niet te wachten tot een (eventuele) volgende evaluatie van de gehele Wkkgz.

Naast de zojuist genoemde fundamentele punten, die direct betrekking hebben op de doelbereiking van de Wkkgz, is een aantal meer organisatorische vraagstukken rondom het functioneren van de geschilleninstanties zichtbaar geworden.

Het eerste punt betreft de financiering van de geschilleninstanties. De kosten van de geschilleninstanties komen voor rekening van de zorgaanbieder c.q. de sector; de klager kan verplicht worden een gering griffierecht te betalen, dat hij terugkrijgt als de instantie hem geheel of gedeeltelijk gelijk geeft. Het onderzoek laat zien dat er verschillende financieringsregelingen bestaan. Soms worden de kosten omgeslagen over een groep zorgaan- 
bieders of een hele deelsector, in andere gevallen worden de kosten gedragen door de zorgaanbieder tegen wie het geschil gericht is. Dat kan leiden tot kosten in de orde van grootte van $€ 1.500$ tot $€ 3.000$ per zaak, ongeacht de uitkomst daarvan. Er zijn aanwijzingen dat dit in de praktijk leidt tot perverse prikkels: zorgaanbieders kopen soms klagers af, ongeacht of deze gelijk hebben of niet. In die benadering levert immers ieder schikkingsbedrag dat lager is dan de zaakkosten van een procedure bij de geschilleninstantie 'winst' op.

Het onderzoek wijst uit dat inmiddels sprake is van 41 erkende geschilleninstanties, die op jaarbasis lang niet allemaal veel werk hebben. Sommige commissies hebben sinds 2016/2017 nog geen enkel geschil ontvangen, andere commissies enkele tientallen. In termen van het opbouwen van kennis en ervaring binnen de instanties laat de huidige situatie een veel te versnipperd beeld zien. Tijdens de parlementaire behandeling van de Wkkgz benadrukte de minister het belang van deskundige instanties. De huidige situatie draagt daar onvoldoende aan bij.

Artikel 22 lid 3 Wkkgz bepaalt dat geschilleninstanties hun uitspraken openbaar maken, zodat van de inhoud ervan geleerd kan worden. Deze uitspraken worden echter niet op één plek verzameld, en zijn daardoor lastig vindbaar. Het is belangrijk één duidelijke online-verzamelplek in te richten, zoals ook met de uitspraken van tuchtcolleges het geval is.

Voor patiënten die aan de geschilleninstantie een verzoek om schadevergoeding voorleggen is nog het volgende van belang. Geschilleninstanties doen uitspraak bij bindend advies. Het bindend advies is een bijzondere vorm van de vaststellingsovereenkomst (art. 7:900 BW). Dat betekent dat het daarna in beginsel niet mogelijk is om op de daarin gemaakte afspraken terug te komen. Daarom moeten hoge eisen worden gesteld aan de voorafgaande informatieverstrekking aan de patiënt. ${ }^{13}$ Voor veel patiënten zal vooraf niet (altijd) duidelijk zijn dat zij na de geschillenprocedure geen beroepsmogelijkheid meer hebben. Het is daarom belangrijk dat zij tijdig adequate informatie krijgen over de aard en consequenties van de geschillenprocedure. De zorgaanbieder is in de beste positie om dat te doen, en kan daartoe informatiemateriaal ontwikkelen of gebruik maken van informatiemateriaal van anderen (zoals een door de overheid of een branche- of consumentenorganisatie ontwikkelde folder).

Aanbevelingen thema 3

Thema 3: De geschilleninstantie

- Aanbeveling 23: Doe verdiepend onderzoek naar het functioneren van de geschilleninstanties Wkkgz, op zichzelf bezien en in relatie tot de Wkkgzklachten- en geschillenregeling als geheel (ministerie).

- Aanbeveling 24: Introduceer een systeem waarin de kosten van de geschilleninstantie worden omgeslagen over een hele deelsector of beroepsgroep, zodat individuele zorgaanbieders door deze kosten niet langer onevenredig getroffen worden (ministerie, beroepsorganisaties).

13 B.S. Laarman, 'De informatieplicht van de zorgaanbieder bij de afwikkeling van medische schade', TVP 2018, afl. 3, p. 89-100. 
- Aanbeveling 25: Stimuleer dat het landschap van geschilleninstanties zo wordt ingericht dat elke instantie voldoende kennis en ervaring kan opbouwen; houd rekening met sectorale deskundigheid door binnen een instantie zo nodig verschillende kamers in te richten (ministerie, beroepsorganisaties).

- Aanbeveling 26: Maak de uitspraken van geschilleninstanties op grond van de Wkkgz op één vaste plaats (website) toegankelijk (ministerie).

- Aanbeveling 27: Specificeer in de wet dat patiënten en hun naasten tijdig informatie ontvangen over de aard en consequenties van de geschillenprocedure (wetgever).

\section{Slotbeschouwing}

De evaluatie van de Wkkgz laat zien dat voor de uitgangspunten en de opzet van de wet een breed draagvlak bestaat. De algemene indruk is ook dat de wet aan het bevorderen van de doelen ervan, het verbeteren van zowel de kwaliteit van zorg als de rechtspositie van de patiënt, ook daadwerkelijk bijdraagt. De verhouding tussen beide doelen is behoorlijk in balans, maar gewaakt moet worden voor spanning tussen deze doelen. Deze algemene conclusies doen er niet aan af dat op tal van punten verbeteringen of aanpassingen mogelijk en gewenst zijn. In dit artikel hebben we drie onderwerpen besproken waarbij dat het geval is. Met name de bevindingen met betrekking tot de geschilleninstanties zijn zorgelijk. 